\title{
Familial isolated arrhythmogenic right ventricular dysplasia
}

INSERM

\section{Source}

INSERM. (1999). Orphanet: an online rare disease and orphan drug data base. Familial isolated arrhythmogenic right ventricular dysplasia. ORPHA:217656

Familial isolated arrhythmogenic right ventricular dysplasia (ARVC) is the familial autosomal dominant form of ARVC (see this term), a heart muscle disease characterized by life-threatening ventricular arrhythmias with left bundle branch block configuration that may manifest with palpitations, ventricular tachycardia, syncope and sudden fatal attacks, and that is due to dystrophy and fibro-fatty replacement of the right ventricular myocardium that may lead to right ventricular aneurysms. 